\title{
The role of built environment energy efficiency in a sustainable UK energy economy ${ }^{\text {is }}$
}

\author{
Joseph A. Clarke, Cameron M. Johnstone, Nicolas J. Kelly*, Paul A. Strachan, Paul Tuohy \\ Energy Systems Research Unit, Department of Mechanical Engineering, University of Strathclyde, Glasgow G1 1XJ, UK
}

\section{A R T I C L E I N F O}

Available online 31 October 2008

Keywords:

Construction

Energy efficiency

Building regulations

\begin{abstract}
A B S T R A C T
Energy efficiency in the built environment can make significant contributions to a sustainable energy economy. In order to achieve this, greater public awareness of the importance of energy efficiency is required. In the short term, new efficient domestic appliances, building technologies, legislation quantifying building plant performance, and improved building regulations to include installed plant will be required. Continuing these improvements in the longer term is likely to see the adoption of small-scale renewable technologies embedded in the building fabric. Internet-based energy services could deliver low-cost building energy management and control to the mass market enabling plant to be operated and maintained at optimum performance levels and energy savings quantified. There are many technology options for improved energy performance of the building fabric and energy systems and it is not yet clear which will prove to be the most economic. Therefore, flexibility is needed in legislation and energy-efficiency initiatives.
\end{abstract}

๑ 2008 Queen's Printer and Controller of HMSO. Published by Elsevier Ltd. All rights reserved.

\section{Introduction}

The profligate material and energy consumption of the built environment dictate that the construction sector has a pivotal role to play in shaping a sustainable energy economy. This paper presents an overview of the current status and potentials within the sector and identifies the technical systems and policy mechanisms by which these potentials may be realised.

\section{Background}

The built environment accounts for an estimated $40 \%$ of total UK energy consumption (European Commission, 2005), while arguably more than $50 \%$ of all UK carbon emissions can be attributed to energy use in buildings (including residential and business emissions, and power station emissions attributable to built environment electricity consumption) (Department for Environment, Food and Rural Affairs, 2008). The built environment therefore has a vital role to play in delivering a sustainable energy economy as recognised by the UK Government in recent Energy White Papers (Department of Trade and Industry, 2003a, 2007) and Energy Efficiency Action Plans (Department for

\footnotetext{
While the Government Office for Science commissioned this review, the views are those of the author(s), are independent of Government, and do not constitute Government policy.

* Corresponding author. Tel.: +44141548 2854; fax: +44141552 5105.

E-mail address: esru@esru.strath.ac.uk (N.J. Kelly).
}

Environment Food and Rural Affairs, 2007a). A chapter in the 2007 White Paper outlined measures designed to reduce built environment carbon emissions by up to $11.7 \mathrm{MtC} / \mathrm{yr}$ by 2020 . This is equivalent to $8 \%$ of total UK emissions in 2005 (AEA Technologies, 2007a). These measures include radical yearon-year improvements to building standards (aiming to deliver zero-carbon new homes by 2016), higher standards for energyconsuming products and the implementation of carbon reduction commitments for large organisations.

Such ambitious policy aims are in contrast to a worrying $15 \%$ rise in overall energy consumption (heat and power) between 1990 and 2005, resulting in no substantial carbon emission reductions since the mid-1990s (Department for Environment, Food and Rural Affairs, 2007b). In the domestic sector, increasing energy consumption has been driven by a multitude of factors: a $30 \%$ increase in the number of households since 1970 (Self and Zealey, 2007); the deployment of central heating in over $90 \%$ of UK households; and the doubling of power consumption by appliances since 1970 (Shorrock and Utley, 2003). At the same time, the UK has a legacy of poorly performing buildings, with $85 \%$ of the housing stock being more than 20 years old (Self and Zealey, 2007). A consequence of this is that, while central heating has increased average indoor air temperatures by $6^{\circ} \mathrm{C}$ since 1970 (Shorrock and Utley, 2003), it has been at the expense of energy efficiency because of inadequate thermal insulation levels. The poor quality of the building stock has also contributed to the situation where an estimated 2.5 million households are classified as fuel poor (Department for Business Enterprise and Regulatory Reform, 2007). In the non-domestic sector, a similar picture 
emerges, with energy consumption increasing by $17 \%$ between 1990 and 2003 (Department of Trade and Industry, 2003b), driven by trends such as the explosion in information technology, poorly regulated and designed speculative developments, and the often unnecessary installation of air conditioning; the energy consumption associated with air conditioning is projected to rise $25 \%$ by 2020 (AEA Technologies, 2007b). Further, it has been estimated that $40 \%$ of the energy used in non-domestic buildings over 10 years old is wasted due to poorly maintained plant and fabric (Johnson, 1993).

The current low levels of energy efficiency in the built environment offer vast scope for improvement in energy performance, which may be achieved through the deployment of an array of techniques ranging from simple plant and insulation upgrades to the deployment of advanced energy monitoring and control.

\section{The potential for energy and emissions savings in buildings}

Prior to 1981, the energy performance of buildings was essentially unregulated. Since then, building regulations have been steadily improved and their scope expanded so that carbon emissions for heating, hot water, ventilation and lighting energy use are now included in design compliance calculations (Office of the Deputy Prime Minister, 2007; Scottish Building Standards, 2007b).

\subsection{Improvements to new and existing buildings}

The current carbon emissions of a typical UK house are around 7.5 tonnes $\mathrm{CO}_{2} / \mathrm{yr}$. If such a property was upgraded to the 2002 fabric standards and a modern gas heating system installed, its performance would improve to around 3.8 tonnes $\mathrm{CO}_{2} / \mathrm{yr}$ (Energy Saving Trust, 2003). Further significant savings in energy and carbon emissions are possible; Olivier (2001), for example, has estimated that the super-insulation of dwellings could result in savings in heat energy of up to $80 \%$.

The majority of the existing housing stock was constructed prior to the development of building energy standards and, to date, the mechanisms for improvement have been governmentsponsored voluntary initiatives promoting efficiency upgrades or low-carbon technologies. The result has been the sporadic application of upgrades. For example, $54 \%$ of cavity-walled homes have no cavity insulation (Utley et al., 2006). A recent detailed study of a local authority housing stock of around 8000 dwellings concluded that a $50 \%$ reduction in carbon emissions could be achieved by conventional fabric and systems upgrades, while a further $50 \%$ reduction was achievable through the deployment of renewable energy systems, heat pumps and combined heat and power plant. This study also illustrated the potential for net carbon neutrality through local, commercial-scale wind farms (Tuohy et al., 2006). Another study considered the space heating energy demand of the entire Scottish housing stock and concluded that a 50\% reduction could be achieved through conventional fabric and system upgrades (Clarke et al., 2007).

In the non-domestic sector, energy savings are highly dependent on the building type. Consider a naturally ventilated, open-plan office as an example. Typically, this would have a carbon emission of approximately $70 \mathrm{kgCO} / \mathrm{m}^{2} \mathrm{yr}$. If this were refurbished to 2002 standards, emissions would fall to $40 \mathrm{~kg}$ $\mathrm{CO}_{2} / \mathrm{m}^{2} \mathrm{yr}$. With an air-conditioned office, typical emissions would be around $140 \mathrm{~kg} \mathrm{CO}_{2} / \mathrm{m}^{2} \mathrm{yr}$ : upgrading to 2002 standards would save around $78 \mathrm{~kg} \mathrm{CO} / \mathrm{m}^{2} \mathrm{yr}$ (Energy Efficiency Office, 2000). Again, further significant improvements in emissions and energy consumption are possible through the implementation of non-standard technologies. For example, controllers linked to occupancy and/or daylight sensors offer the potential to reduce lighting electricity consumption by 40-90\% (Holtz, 1990; Knight, 1999).

\subsection{Improved appliance efficiency}

There is significant scope for improvement in the energy used by appliances. For example, a recent publication by a computing industry consortium (Climatesavers, 2007) identified the potential for a $40 \%$ reduction in power use from IT equipment by 2011, while a US Environmental Protection Agency (2007) report identified the potential for a 50\% reduction in the energy used by computer servers. The positive impact of reduced energy for IT could also provide a secondary benefit in reduced heat gains, more comfortable environments and lower cooling energy use.

\subsection{Achieving energy and emissions savings in practice}

The improvements discussed above are potentials, with the translation into real energy savings and emissions reductions strongly dependent on the uptake of improvement measures. Two recent research projects: the $40 \%$ house (Environmental Change Institute, 2005) and building market transformation (Boardman, 2007) identified the actions required to meet the Government's aspiration for a $60 \%$ reduction in carbon emissions by 2050 , as outlined in the 2003 Energy White Paper (Department of Trade and Industry, 2003a). These projects used a housing stock model, incorporating future population and building occupancy trends, to analyse scenarios covering different rates of uptake of low-carbon technologies. The conclusion was that, in order to meet the $60 \%$ target, there needs to be a profound change within the built environment. Moreover, realising the carbon potential of improvements is also dependent on the quality of implementation of energy-saving measures. There are many examples where lowenergy buildings have been monitored and their energy consumption shown to be substantially greater than expected (Bordass et al., 2001). The discrepancy is often found to be due to poor-quality construction (e.g. missing insulation, significant thermal bridging, etc.), and systems control. Such problems highlight the need for more attention to commissioning, skills improvement through training and the post-construction monitoring of energy performance to support the enforcement of standards. The introduction of air-tightness sampling into the 2006 and 2007 building regulations provides one check on the implementation of building energy-efficiency measures, while the introduction of thermo-graphic imaging and moves towards operational energy certificates in England and Wales provides others.

\section{Implementation initiatives}

The energy-savings potential discussed above can only be realised where mechanisms are in place to ensure the upward trend in building energy performance and, where necessary, enforce minimum standards. To this end, there have been several important UK/EU policy initiatives in recent years as follows.

\subsection{Improving new build}

In new buildings, the main driver towards increased energy efficiency is legislative. The recent EU Energy Performance of Buildings Directive (EPBD) (European Union, 2002) has led to the development of the UK National Calculation Methodology (NCM) 
for non-domestic buildings, which is embedded either in a Simplified Building Energy Model (SBEM) or accredited building energy simulation tools. The NCM is being used to provide energy certificates and prove building compliance for non-domestic buildings, while the UK Government's Standard Assessment Procedure (Building Research Establishment, 2005) is used for domestic buildings.

Both the Scottish (Scottish Building Standards, 2007a) and Westminster Governments (Department for Communities and Local Government, 2007) have issued strategy documents outlining proposed 2010, 2013 and 2016 carbon emission targets, while the latter has stated that by 2016 there will be a reduction in tax for buildings that have net zero carbon emissions over all energy uses, including energy for appliances and cooking (Hansard, 2007). These improvements in regulations have the potential for reduced energy use in new buildings and may be expected to bring the UK into alignment with European benchmarks (European Union Passivehouse, 1997).

\subsection{Improving existing buildings}

There are a number of initiatives to deliver energy and $\mathrm{CO}_{2}$ savings in existing buildings, each reflecting the UK Government's historical preference for employing fiscal incentives rather than legislation for retrospective energy performance improvements. In 2003/2004, the total budget for these initiatives was nearly $£ 270$ million (Kelly, 2006), with delivery generally devolved to bodies such as the Carbon Trust and the Energy Saving Trust. The Carbon Trust focuses on aiding large industry consumers in adopting energy-efficiency practices and technologies. The Energy Saving Trust supports Energy Efficiency Advice Centres that help domestic and small commercial consumers. Additionally, power utilities are obliged under the Energy Efficiency Commitment scheme to provide help and assistance (usually in the form of grants) to consumers to assist them in reducing their energy bills.

There are increasing indications that the future driver for improvements in the existing building stock will be legislation and enforcement. For example, Energy Performance Certificates are a mechanism for setting mandatory minimum standards for existing dwellings. Other components of the EPBD are the requirements for regular inspection of boilers and air-conditioning equipment, and checks on building air-tightness. By focusing on actual systems and their operational energy ratings, rather than expected energy use, such measures should ensure that theoretical energy savings are achieved in practice.

\subsection{Skills enhancement}

Over a decade ago, the Latham report (Latham, 1994) recognised the chronic shortage of skilled workers within the construction industry and identified that there was also a lack of training and education. Such shortages are still apparent, and upskilling of the construction workforce will be a major challenge to improve the quality of future buildings and ensure the correct installation of the wide variety of new and renewable technologies such as those discussed below.

\section{Future technologies}

While institutions, legislation and improved practice in the construction sector can go some way to reducing emissions and energy consumption, a step-change in performance will require the integration of new technologies in both energy supply and demand. As a result of a sustained research effort over the last two decades, many technology options are available that could help bring about this step-change. While these options are as yet unable to compete economically, this situation may be expected to improve as the low-carbon market develops and energy costs rise.

\subsection{Smart façades}

Examples of this technology include: advanced glazings providing high insulation and/or solar/daylight capture/exclusion (Campagno, 1999); transparent insulation material to reduce construction heat loss and capture solar energy; breathable insulation for the passive pre-heating of ventilation air; and novel shading and light redirecting devices to alleviate overheating and/ or enhance solar energy and daylight capture. Advanced daylight utilisation systems incorporating integrated control of artificial lighting are particularly attractive because they directly displace electricity use while improving the indoor visual environment (Fontoynont, 1999).

\subsection{Solar energy collection/conversion}

Passive solar features may be deployed to collect and deliver heating, lighting and ventilation (e.g. Porteous and MacGregor, 2005; Stephens, 1996). Examples include Trombe-Michel walls, sunspaces, mass walls, glazed atria, thermo-siphon air panels, solar ventilation pre-heat and light shelves. Active solar devices include roof-mounted solar thermal collectors to provide a contribution to hot water, and photovoltaic components to convert solar energy to heat and electricity, with the latter output used locally or exported to the electric grid. Solar technologies can bring about significant reductions in building lighting and space/ water heating demands, respectively, reshaping the demand profile to better accommodate active renewable sources of energy.

\subsection{Building integrated renewables}

Such systems produce thermal and/or electrical power locally and thereby minimise the demand placed on the public energy supply infrastructure. For example, photovoltaic components and encased wind turbines may be deployed, with the public electricity supply accessed when the renewable resource is unavailable. Such co-operative systems have been shown to reduce the consumption of conventionally generated electricity by up to $90 \%$ (Born et al., 2001).

\subsection{Heat and power systems}

Air- and ground-source heat pumps may be used as an apt replacement for gas-fired boilers within existing heating systems at both the individual building and district levels (Berntsson, 2002; Harvey, 2006). Ground-source heat pumps, for example, can operate with a coefficient of performance of around four; that is, one unit of electricity is consumed to supply four units of useful heat. Further, as the primary fuel is electricity, heat pumps are well aligned with a future scenario, where uncertain or diminishing natural gas supplies are replaced by electricity derived from renewable energy sources and nuclear power. However, in the near future combined heat and power systems (CHP), utilising oil, gas or biofuels, may be expected to underpin decentralised energy solutions: the Government's target is to double CHP capacity in the UK to $10,000 \mathrm{MW}$ by 2010 (Combined Heat and Power Association: www.chpa.co.uk/). Fuel cells for application within buildings, while potentially carbon-neutral, are still at the research and development stage, with high capital cost and uncertain performance in the field. 
Notwithstanding the maturity of the above energy supply technologies, significant deployment challenges exist, particularly ensuring adequate skill levels among those who will design, install and maintain systems.

\subsection{Electrical appliances}

Despite the existence of energy labelling schemes, financial incentives and increased public awareness of energy, the number and variety of electrical appliances continues to rise. To compound the problem, the power consumption of new devices is often greater than that of the obsolete device they seek to replace (e.g. plasma televisions). The Energy Saving Trust (2007) has estimated that, by 2020, consumer electronics and ICT will account for around $45 \%$ of domestic energy use. The challenge is to reverse this upward trend through radical improvements in appliance energy efficiency and the elimination of stand-by losses.

\subsection{Internet-enabled energy services}

The internet is effectively juxtaposed with the energy network and this offers the prospect of establishing a range of energy services concerned with cost-effective energy use, monitoring and control, and enhanced user participation in energy-efficiency initiatives (Clarke et al., 2002). By embedding low-cost sensors within buildings, it is possible to transmit high-frequency data on environmental conditions and appliance power consumption to service providers, who then deliver appropriate services: energyuse statistics to regulatory bodies, the remote control of appliances to households, the management of micro-grids to utilities and so on.

\subsection{Design tools}

The ability to model a building's energy performance has been a reality since the early 1980s and the benefits have been well documented (McElroy et al., 2001). However, the use of modelling has not been widespread in the UK. The adoption of the EPBD in the UK through the new building regulations is a first step to ensuring that energy modelling becomes an integral part of the design process. The need for explicit modelling is becoming palpable, with the emergence of the myriad energy supply and demand reduction technologies mentioned above as the approach allows practitioners to match technologies to particular building types and contexts. In this way, it is possible to ensure supply matches demand over time, which is particularly problematic in designs incorporating stochastic renewable sources. Finally, strategic energy modelling can provide the data needed to develop more robust energy policies at the regional and national levels (Clarke, 2003; Clarke et al., 2004).

\subsection{Smart metering}

There is likely to be a rapid increase in smart metering of energy usage in the future, giving consumers up-to-date information on their consumption. There is mounting evidence that providing such information can lead to significant reductions in consumption (Darby, 2000).

\section{Conclusions}

This paper has highlighted the importance of the built environment in relation to UK energy consumption. It highlighted the current poor energy performance of many buildings and the upward trend in consumption, which has been exacerbated by historically weak performance standards, demographic trends and the increase in electrical appliance usage. Despite the worrying trend, the potential for building energy efficiency is substantial, with even relatively basic measures delivering dramatic improvements. With the advent of the EPBD, the present supportive environment for improved energy performance that exists in the UK is being augmented by the means to enforce compliance in new and existing buildings.

Finally, the paper has summarised the principal emerging technologies that could assist in achieving a radical step-change in energy performance, identified the need for construction industry upskilling to ensure effective installations, and underlined the need for better public engagement in energy performance issues.

\section{References}

AEA Technologies, 2007a. Greenhouse gas inventories for England, Wales, Scotland and Northern Ireland. EPEO/ED05452200.

AEA Technologies, 2007b. BNAC18: modelling the energy consumption of air conditioning. Market Transformation Programme Policy Briefing.

Berntsson, T., 2002. Heat sources-technology economy and environment. International Journal of Refrigeration 25, 428-438.

Boardman, B., 2007. Reducing the environmental impact of housing. Environmental Change Institute 〈http://www.eci.ox.ac.uk/research/energy/bmt.php 〉 (accessed 20 May 2008).

Bordass, B., Leaman, A., Ruyssevelt, P., 2001. Assessing building performance in use 5: conclusions and implications. Building Research and Information 29 (2), 144-157.

Born, F.J., Clarke, J.A., Johnstone, C.M., Kelly, N.J., Burt, G., Dysko, A., McDonald, J., Hunter, I.B.B., 2001. On the integration of renewable energy systems within the built environment. Building Services Engineering Research and Technology 22 (1), 3-13.

Building Research Establishment, 2005. The UK Governments Standard Assessment Procedure: 〈http://projects.bre.co.uk/sap2005/〉 (accessed 20 May 2008).

Campagno, A., 1999. Intelligent Glass Façades, fourth ed. Birkhauser, Switzerland.

Clarke, J.A., 2003. IT systems for energy and environment monitoring, planning, design and control. In: State-of-the-art in Solar Thermal Technologies for Buildings. James \& James, London.

Clarke, J.A., Johnstone, C.M., Kim, J., Strachan, P.A., 2002. On-line energy services for smart homes. In: Proceedings of the EPIC '02, Lyon, October.

Clarke, J.A., Johnstone, C.M., Kondratenko, I., Lever, M., McElroy, L.B., Prazeres, L., Strachan, P.A., McKenzie, F., Peart, G., 2004. Using simulation to formulate domestic sector upgrading strategies for Scotland. Energy and Buildings 36, 759-770.

Clarke, J., Johnstone, C., Kim, J., Tuohy, P., 2007. Energy and carbon performance of housing: upgrade analysis. In: Energy Labelling and National Policy Development, 28th AIVC Conference, Crete.

Climatesavers, 2007. Climate savers computing initiative white paper: 〈www. climatesaverscomputing.org/media/whitepaper11302007.pdf $\rangle$ (accessed 20 May 2008).

Combined Heat and Power Association:〈http://www.chpa.co.uk/〉 (accessed 20 May 2008).

Darby, S., 2000. Making it obvious: designing feedback into energy consumption. In: Proceedings of the Second International Conference on Energy Efficiency in Household Appliances and Lighting. Italian Association of Energy Economists/ EC-SAVE Programme.

Department for Business Enterprise and Regulatory Reform, 2007. The UK Fuel Poverty Strategy. Fifth Annual Progress Report, URN 07/353. The Stationery Office, London.

Department for Communities and Local Government, 2007. Building regulations: a look forward to what standards may be in 2010 and 2013: <http://www.communities.gov.uk/publications/planningandbuilding/ energyefficiencynewdwellings $\rangle$ (accessed 20 May 2008).

Department for Environment, Food and Rural Affairs, 2007a. Energy Efficiency Action Plan, PB12615. The Stationery Office, London.

Department for Environment, Food and Rural Affairs, 2007b. Sustainable Development Indicators in Your Pocket 2007. The Stationery Office, London.

Department for Environment, Food and Rural Affairs, 2008. E-Digest of Statistics: 〈http://www.defra.gov.uk/environment/statistics/globatmos/gakf07.htm 〉 (accessed 20 May 2008).

Department of Trade and Industry, 2003a. Energy White Paper: Our Energy Future-Creating a Low-Carbon Economy, URN 06/660. The Stationery Office, London.

Department of Trade and Industry, 2003b. Energy Consumption in the United Kingdom, URN 02/1049. The Stationery Office, London.

Department of Trade and Industry, 2007. Energy White Paper: Meeting the Energy Challenge, CM 7124. The Stationery Office, London. 
Energy Efficiency Office, 2000. Energy Use in Offices, reprint. ECGO19: <http:// www.carbontrust.co.uk/Publications/publicationdetail.htm?productid=ECG019\& metaNoCache $=1>$ (accessed 20 May 2008).

Energy Saving Trust, 2003. Energy Efficient Refurbishment of Existing Housing GPG155: < http://www.energysavingtrust.org.uk/uploads/documents/housing buildings/CE83.GPG155\%20-\%20Energy\%20efficient\%20refurbishment\%20of\% 20existing\%20dwellings_4_01_08.pdf > (accessed 20 May 2008).

Energy Saving Trust, 2007. The ampere strikes back: how consumer electronics are taking over the world: 〈http://www.energysavingtrust.org.uk/download.cfm? $\mathrm{p}=4 \&$ pid $=1085>$ (accessed 20 May 2008).

Environmental Change Institute, 2005. 40\% House. Environmental Change Institute, Oxford.

Environmental Protection Agency, 2007. Report to Congress on Server and Data Center Energy Efficiency, Public Law 109-431. US Environmental Protection Agency Energy Star Program.

European Commission, 2005. Challenging and Changing Europe's Built Environment: A Vision for a Sustainable and Competitive Construction Sector by 2030 European Construction Technology Platform.

European Union, 2002. On the Energy Performance of Buildings. Directive 2002/ 91/EC of the European Parliament.

European Union Passivehouse, 1997. Cost efficient passive houses as European Standards. THERMIE Project BU/0127/97: 〈http://www.cepheus.de 〉 (accessed 20 May 2008).

Fontoynont, M. (Ed.), 1999. Daylight Performance of Buildings. Prepared for the European Commission Directorate General XII. James \& James, London.

Hansard, 2007. Column WS55, 18 October: 〈http://www.publications.parliament. uk/pa/ld200607/ldhansrd/text/71018-wms0001.htm > (accessed 20 May 2008).

Harvey, L.D.D., 2006. A Handbook on Low-Energy Buildings and District-Energy Systems. Earthscan, London.

Holtz, M., 1990. Electrical Energy Savings in Office Buildings. Swedish Council for Building Research, Stockholm.

Johnson, S., 1993. Greener Buildings: The Environmental Impact of Property. MacMillan Press, Hong Kong.

Kelly, N.J., 2006. The vital role of demand reduction in reducing Scotland's $\mathrm{CO}_{2}$ emissions. Energy Policy 34 (18), 3505-3515.
Knight, I.P., 1999. Measured energy savings due to photocell control of individual luminaires. International Journal of Lighting Research and Technology (CIBSE) 31.

Latham, M., 1994. Constructing the team. Final Report of the Government's Industry Review of Procurement and Contractual Arrangements in the UK Construction Industry. HMSO, London.

McElroy, L.B., Clarke, J.A., Hand, J.W., Macdonald, I.A., 2001. Delivering energy simulation to the profession: the next stage. In: Proceedings of the Building Simulation '01, Rio de Janeiro.

Office of the Deputy Prime Minister, 2007. English and Welsh Building Regulations, National Building Specification, London: <http://www.planningportal.gov.uk/ england/professionals/en/1115314110382.html > (accessed 20 May 2008).

Olivier, D., 2001. Building in Ignorance: Demolishing Complacency-Improving the Energy Performance of 21 st Century Homes. Association for the Conservation of Energy, London.

Porteous, C., MacGregor, K., 2005. Solar Architecture in Cool Climates. Earthscan, London.

Scottish Building Standards, 2007a. A Low Carbon Building Standards Strategy for Scotland (The Sullivan Report), 〈http://www.sbsa.gov.uk/sullivanreport.htm 〉 (accessed 20 May 2008).

Scottish Building Standards, 2007b. Scottish Building Regulations, <http://www. sbsa.gov.uk/tech_handbooks/tbooks2007.htm $>$ (accessed 20 May 2008).

Self, A., Zealey, L. (Eds.), 2007. Social Trends 37. Office for National Statistics, Palgrave Macmillan, Basingstoke, New York.

Shorrock, L.D., Utley, J.I., 2003. Domestic Energy Fact File 2003. Building Research Establishment Housing Centre, BRE Publications, Watford.

Stephens, H.S. (Ed.), 1996. Proceedings of the Solar Energy in Architecture and Urban Planning, Berlin.

Tuohy, P.G., Strachan, P.A., Marnie, A., 2006. Carbon and energy performance of housing: a model and toolset for policy development applied to a local authority housing stock. In: Proceedings of the Eurosun, Glasgow.

Utley, J.I., Shorrock, L., Brown, J.H.F., 2006. Domestic energy fact file: England, Scotland, Wales and Northern Ireland. Building Research Establishment Report, BRE Bookshop, London. 